\title{
Low Temperature Synthesis of Zeolites of the Faujasite Family (FAU-EMT) Using Industrial Mineral Waste (FR) from Silane Production
}

\author{
Valeriy Petrov, Josef-Christian Buhl* \\ Institute of Mineralogy, Leibniz University Hannover, Hannover, Germany \\ Email: j.buhl@mineralogie.uni-hannover.de
}

How to cite this paper: Petrov, V. and Buhl, J.-Ch. (2017) Low Temperature Synthesis of Zeolites of the Faujasite Family (FAU-EMT) Using Industrial Mineral Waste (FR) from Silane Production. Journal of Materials Science and Chemical Engineering, 5, 1-13.

https://doi.org/10.4236/msce.2017.511001

Received: October 11, 2017

Accepted: November 7, 2017

Published: November 10, 2017

Copyright $\odot 2017$ by authors and Scientific Research Publishing Inc. This work is licensed under the Creative Commons Attribution International License (CC BY 4.0).

http://creativecommons.org/licenses/by/4.0/

\begin{abstract}
Zeolite formation was investigated under low temperature conditions between $40^{\circ} \mathrm{C}-25^{\circ} \mathrm{C}$ under insertion of a Si-rich filtration residue (FR) from waste water cleaning of the silane production. Syntheses were performed under open system conditions without stirring. The application of templates was excluded but gel formation was optimized by addition of citric acid. Beside a minimal consumption of process energy during synthesis under very low temperatures even FR was inserted without an expansive pre-treatment like calcination. Disordered intergrowths of FAU-EMT intermediates were obtained in each case, even at a temperature of only $25^{\circ} \mathrm{C}$. The reaction products always occurred in two sequences, one at the bottom and another at the top of the reaction bin. A better crystallinity was detected for the latter products and the $\mathrm{Si} / \mathrm{Al}$ ratio of these FAU-EMT members was close to 1.0 like in zeolite LSX. In contrast chemical analyses revealed an enrichment of $\mathrm{Ca}$ - and $\mathrm{Mg}$ impurities from FR in the bottom products.
\end{abstract}

\section{Keywords}

FAU-EMT Zeolites, Disordered Intergrowths, Industrial Waste, $25^{\circ} \mathrm{C}$ Synthesis

\section{Introduction}

Investigations on the recycling of industrial rest materials are significant for reasons of the environment protection as well as the recovery of valuable ingredients. In this sense the objective of the present work is the experimental study of zeolite synthesis under insertion of a silica-rich filtration residue "FR" obtained from waste water reconditioning of the silane production. $\mathrm{SiO}_{2}$ rich 
wastes like slags, ashes, filtration residues and related materials are often suitable educts for zeolite synthesis, as demonstrated in a large number of former investigations [1]-[8]. A high content of $\mathrm{SiO}_{2}$ and sometimes also $\mathrm{Al}_{2} \mathrm{O}_{3}$ as well as sodium, potassium or calcium, favors these residues as substitutes within the educts of zeolite synthesis but always only under the basic requirement that their chemical composition is without elements or components being harmful to the environment. Newly even wastes like paper sludge combustion ash [9] [10] [11] [12] [13] and filtration residues from industrial waste water cleaning [14] as well as electrostatic filtration ash from combustion of silane production residues [15] were involved in those experimental studies. Important zeolites like LTA, Na-P, SOD or Li-ABW could be prepared therefrom. Often multi-step processes like alkaline digestion of the waste material at elevated temperature before the crystallization step were revealed and the total processes are energy and time consumptive.

In the present work, the synthesis of nanosized members of zeolites of the Faujasite family is reported, using a silica rich filtration residue (FR). The molecular sieve Faujasite finds extensive application as a catalyst for various industrially important processes such as cracking, alkylation, hydrocracking and reforming [16] and is thus increasingly used in the oil-refining industry. In contrast to our previous investigation on hydrosodalite and zeolite Na-A (LTA) formation from $\mathrm{FR}$ at $90^{\circ} \mathrm{C}-60^{\circ} \mathrm{C}[14]$ the aim of the present study is the insertion of the silica rich filtration residue to investigate FAU crystallization in the low temperature range of $40^{\circ} \mathrm{C}-25^{\circ} \mathrm{C}$ i.e. by minimal energy input. Synthesis conditions for zeolites are extensively given in literature [16] [17] [18]. Temperatures in the range of $80^{\circ} \mathrm{C}-90^{\circ} \mathrm{C}$ were typically revealed to synthesize zeolites of structure type FAU [19]. Synthesis of zeolites hydrosodalite, zeolite $\mathrm{NaA}$ and zeolite $\mathrm{NaX}$ were first performed at temperatures at the $70^{\circ} \mathrm{C}-40^{\circ} \mathrm{C}$ range by using superalkaline conditions [20] [21] [22]. The authors inserted pure synthesis chemicals in their experiments. Newly this superalkaline low temperature method was revealed for zeolite formation from industrial wastes like paper sludge combustion ash or silica rich filtration residues from industrial waste water cleaning and already the residue FR of the present paper was tested here [13] [14] [15].

Unfortunately the growth of FAU remained improper during these former experiments as no pure phase product was obtained and temperatures not lower than $60^{\circ} \mathrm{C}$ were necessary [14]. Recently an interesting study was performed by Eng-Poh Ng et al. [23] [24]. The authors obtained nanocrystalline EMT zeolite under insertion of rice husk at $28^{\circ} \mathrm{C}$ [24]. The only disadvantage was the necessity of processing and dissolution of the rice husk according to a calcination at $600^{\circ} \mathrm{C}$ and a dissolution at $100^{\circ} \mathrm{C}$.

In the present paper we investigate possibilities of FAU zeolite formation by a modified superalkaline reaction system under insertion of the residue FR and citric acid to rule gel polymerization and to buffer the whole system in the very low temperature interval of $40^{\circ} \mathrm{C}-25^{\circ} \mathrm{C}$. Sodium hydroxide as mineralizator and 
sodium aluminate additive as Al-source were further inserted. Hydrothermal process guidance with sodium aluminate was already an object of experimental investigations on the recycling of autoclave aerated concrete to zeolite Na-A [25] [26]. The experiments of the present paper are a case study of insertion of industrial waste materials in zeolite chemistry at low temperature.

\section{Experimental}

\subsection{Starting Materials}

The Si-rich filtration residue (FR) was obtained from the waste water cleaning procedure of the silane production. The material (kindly provided from the Federal Institute for Materials and Testing, BAM-Berlin) was dried and finely grounded. The chemical analysis of FR was even performed at BAM [27] with the help of the optical emissions spectrometry with inductively coupled plasma (ICP-OES) under use of an iCAP 6000 device (Thermo Scientific). The analysis results are summarized into Table 1.

An XRD investigation proved that FR is mainly X-ray-amorphous silica and contains only a very low portion of crystalline calcite. A SEM study of FR exhibited a fine-grained material from nano- to microparticles, and rare agglomerates of a size of max. $1 \mu \mathrm{m}$.

Beside FR the following chemicals were used for syntheses:

Sodium aluminate, Riedel-deHaën 13404; sodium hydroxyde, Merck 1.06467 and citric acid, Fluka 27490.

\subsection{Experimental Conditions}

The experimental conditions of the syntheses are summarized in Table 2. All experiments presented here, were performed in the same manner, only synthesis temperature and synthesis time were varied (Table 2). Each synthesis batch consists of a mixture of three separate produced solutions:

Solution (1): $2 \mathrm{~g} \mathrm{FR}+30 \mathrm{ml} \mathrm{H}{ }_{2} \mathrm{O}+17.0 \mathrm{~g} \mathrm{NaOH}$ were mixed by stirring for 45 $\mathrm{min}$. at room temperature (RT);

Solution (2): $20 \mathrm{ml} \mathrm{H}_{2} \mathrm{O}+4.2 \mathrm{~g}$ citric acid (CA), mixed by stirring for $15 \mathrm{~min}$. at RT;

Solution (3): $50 \mathrm{ml} \mathrm{H}{ }_{2} \mathrm{O}+12.6 \mathrm{~g} \mathrm{NaOH}+2.3 \mathrm{~g} \mathrm{NaAlO}_{2}$, mixed by stirring for $15 \mathrm{~min}$. at RT.

The solutions were mixed in ascending order $(1+2+3)$ in a beaker glass.

A total number of three of those complete mixtures were prepared (batch No. 1 - 3, Table 2) and crystallization was performed by heating in a cabinet

Table 1. Chemical composition of the filtration residue FR [27].

\begin{tabular}{ccccccccccc}
\hline \multicolumn{10}{c}{ Chemical composition (Wt. \%)* } \\
\hline $\mathrm{SiO}_{2}$ & $\mathrm{Al}_{2} \mathrm{O}_{3}$ & $\mathrm{Fe}_{2} \mathrm{O}_{3}$ & $\mathrm{TiO}_{2}$ & $\mathrm{CaO}$ & $\mathrm{MgO}$ & $\mathrm{Na}_{2} \mathrm{O}$ & $\mathrm{K}_{2} \mathrm{O}$ & $\mathrm{SO}_{3}$ & $\mathrm{Cl}^{-}$ & Loss of ignition \\
92.30 & 3.83 & 0.49 & 0.05 & 2.05 & 0.19 & 0.01 & 0.05 & 0.23 & 0.80 & 3.23 \\
\hline
\end{tabular}

*standardized on $100 \%$, without glowing loss. 
Table 2. Experimental conditions and synthesis results.

\begin{tabular}{lccccc}
\hline 7 & \multirow{2}{*}{$\begin{array}{c}\text { Temperature } \\
\left({ }^{\circ} \mathrm{C}\right)\end{array}$} & $\begin{array}{c}\text { Time } \\
(\mathbf{h})\end{array}$ & $\begin{array}{c}\text { Qualitative phase } \\
\text { analysis }(\mathrm{XRD})\end{array}$ & Si/Al-ratio & $\begin{array}{c}\text { Total amount } \\
(\mathbf{a}+\mathbf{b})(\mathrm{g})\end{array}$ \\
\cline { 5 - 6 } 1 & 40 & 48 & $\begin{array}{r}\text { a) FAU-EMT and LTA } \\
\text { b) FAU-(EMT) and LTA }\end{array}$ & 1.2 & 1.30 \\
2 & 30 & 72 & $\begin{array}{l}\text { a) FAU-EMT and (LTA) } \\
\text { b) FAU-EMT and (LTA) }\end{array}$ & 1.2 & 1.20 \\
3 & 25 & 96 & a) FAU-EMT & 1.3 & 1.10 \\
\hline
\end{tabular}

*a) Products on the beaker ground; b) products in the upper part of the beaker; (): very low amounts; ${ }^{*}$ Si/Al-ratio of the FAU-EMT intergrowth.

dryer for different times and temperatures without stirring, as summarized in Table 2.

The application of templates was excluded but gel formation was optimized by addition of citric acid. With the application of citric acid we followed the certain aims:

- The additional proton enrichment of the sol/gel in an alkaline environment reduces the polymerization and avoids a too fast flocculation of the gel [28] [29] [30] [31].

- Due to the dissociation strength citric acid is a suitable buffer to rule the kinetics of the reaction course [30] [31].

- Citric acid often removes actually many impurities from the filtration residue besides, the resulting citrate complexes remain dissolved and can be removed with the washing water.

Our former investigations further showed the positive influence of the acid by buffering the reaction system during zeolite syntheses [30] and even no traces of the acid were incorporated inside the zeolite cavities. Under our experimental conditions citric acid exhibits a sufficient stability but did not act as a template for structural modifications of the zeolite product.

\subsection{Characterization}

All products were analysed by X-ray powder diffraction (XRD), scanning electron microscopy (SEM) and energy dispersive X-ray spectroscopy (EDXS).

XRD was performed on a D4 Endeavor diffractometer (Bruker) with $\mathrm{Cu} \mathrm{K} \alpha$ monochromatized radiation (graphite monochromator) at $40 \mathrm{kV}$ and $40 \mathrm{~mA}$. The samples were scanned in the range $3^{\circ}-65^{\circ} 2$ Theta, with a step wide of $0.02^{\circ} 2$ Theta and a measuring time of 3 seconds for each step. The powder patterns (Figure 1) were presented in the $3^{\circ}-40^{\circ} 2$ Theta range for a better overview of the narrow neighboring lines of zeolites of FAU-EMT family and because most of the signals of these zeolites were observed in this interval. 


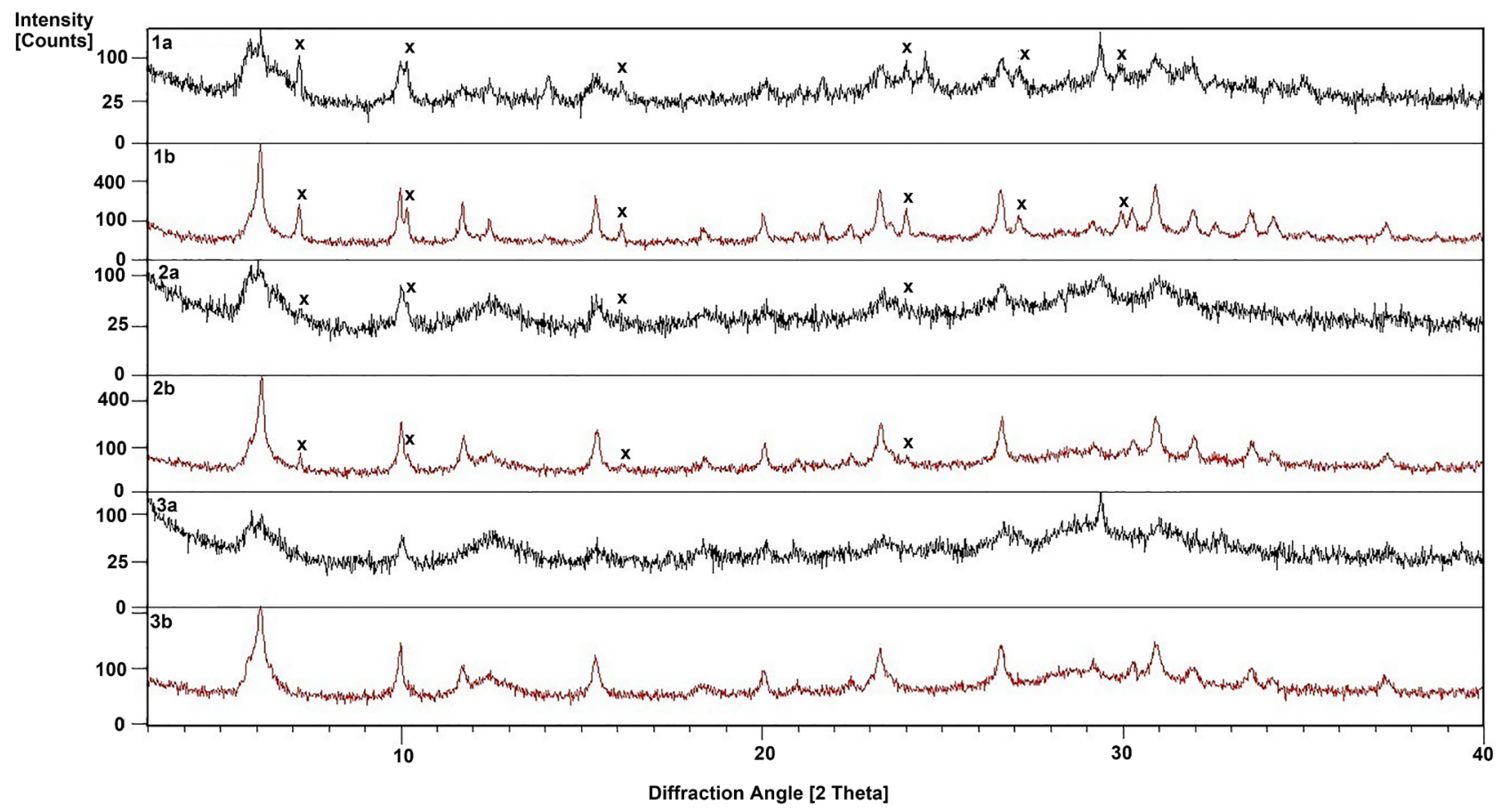

Figure 1. X-ray powder patterns of samples $1 \mathrm{a}, 1 \mathrm{~b}, 2 \mathrm{a}, 2 \mathrm{~b}, 3 \mathrm{a}$, and $3 \mathrm{~b}$. The main lines of the byproduct zeolite LTA in samples $1 \mathrm{a}$, $\mathrm{b}$ and $2 \mathrm{a}, \mathrm{b}$ are marked by asterisk.

The crystal size, morphology and homogeneity of the products were determined by SEM, using a Jeol JSM-6390A and $30 \mathrm{kV}$ acceleration voltage.

The chemical composition of the samples was determined by EDXS with an Xflash Detektor 410-M (Bruker).

\section{Results}

The results of qualitative phase according XRD patterns of Figure 1 are summarized in Table 2. Analysis results were obtained on the basis of powder Data [32], the zeolite structure information atlas [33] and the powder diffraction file PDF [34].

The reaction products of all three syntheses accrued in two sequences:

- on the ground of the reaction glass: here fine disperse nanocrystalline zeolite material was deposited beside more or less amorphous aluminosilicate (samples 1a, 2a and 3a);

- and in the upper area of the reaction glass: here zeolite with somewhat higher crystallinity but even in polycrystalline form was found (samples $1 \mathrm{~b}, 2 \mathrm{~b}$ and $3 b)$;

Hence, it was decided to describe these synthesis products in separate sections:

\subsection{Samples 1a and $1 \mathrm{~b}$}

The X-ray powder pattern of the product $1 \mathrm{a}$ (shown in the $3^{\circ}-40^{\circ} 2$ Theta range for a better overview) in Figure 1 exhibits the lines of two zeolite phases, namely 
the main phase FAU-EMT and an admixture of zeolite LTA. Whereas the lines of the latter phase correspond with PDF card 39-222 (strongest reflex $\sim 7.2^{\circ} 2$ Theta) [34], the signals of the FAU-EMT phase can be characterized according the cards of cubic FAU: PDF 38-237 and of the hexagonal form EMT: PDF 46-566 [34]). In [31] a whole set of simulations of powder patterns of disordered intergrowths of the FAU family is presented in steps of $10 \%$ from $100 \%$ FAU to $100 \%$ EMT. The FAU-EMT intergrowths can be distinguished in a powder pattern according to a typical triplet with reflections at 5.87, 6.24 and $6.65^{\circ} 2$ Theta. These lines are responsible for the broad signals in the low angle region around the $6^{\circ} 2$ Theta reflex of the pattern of product 1a in Figure 1. Beside an intergrowth between FAU and EMT the line broadening in the whole pattern is further influenced by the very low crystal size and the weak crystallinity of the sample. Even the strong background contribution is a further sign for the poor crystallinity of product $1 \mathrm{a}$.

The SEM picture of sample 1a, given in Figure 2, points to a relatively homogeneous product, consisting of extremely small, in one direction slightly stretched crystallites of FAU-EMT and LTA. The crystals cover nearly the whole field of view. The size of the crystallites amounts below $0.1 \mu \mathrm{m}$.

The field analysis according EDXS proved the following chemical composition (Wt.\%): $\mathrm{SiO}_{2}: 46.2 ; \mathrm{Al}_{2} \mathrm{O}_{3}: 31.8 ; \mathrm{Na}_{2} \mathrm{O}: 15.5 ; \mathrm{CaO}: 5.6 ; \mathrm{MgO}: 0.9$. The Si/Al-ratio was $\sim 1.2$.

The XRD analysis of sample $1 \mathrm{~b}$ (Figure 1 , again shown in the $3^{\circ}-40^{\circ} 2$ Theta range for a better overview) presents the crystallization of FAU (PDF 38-237 [34]) as a main phase and LTA (PDF 39-222 [34]). Only weak shoulders around the main FAU line at $6.24^{\circ} 2$ Theta are a hint on a few EMT intergrowths. The higher reflex intensities and the lower background contribution of the whole pattern reveal a higher crystallinity of this sample, compared with product 1a.
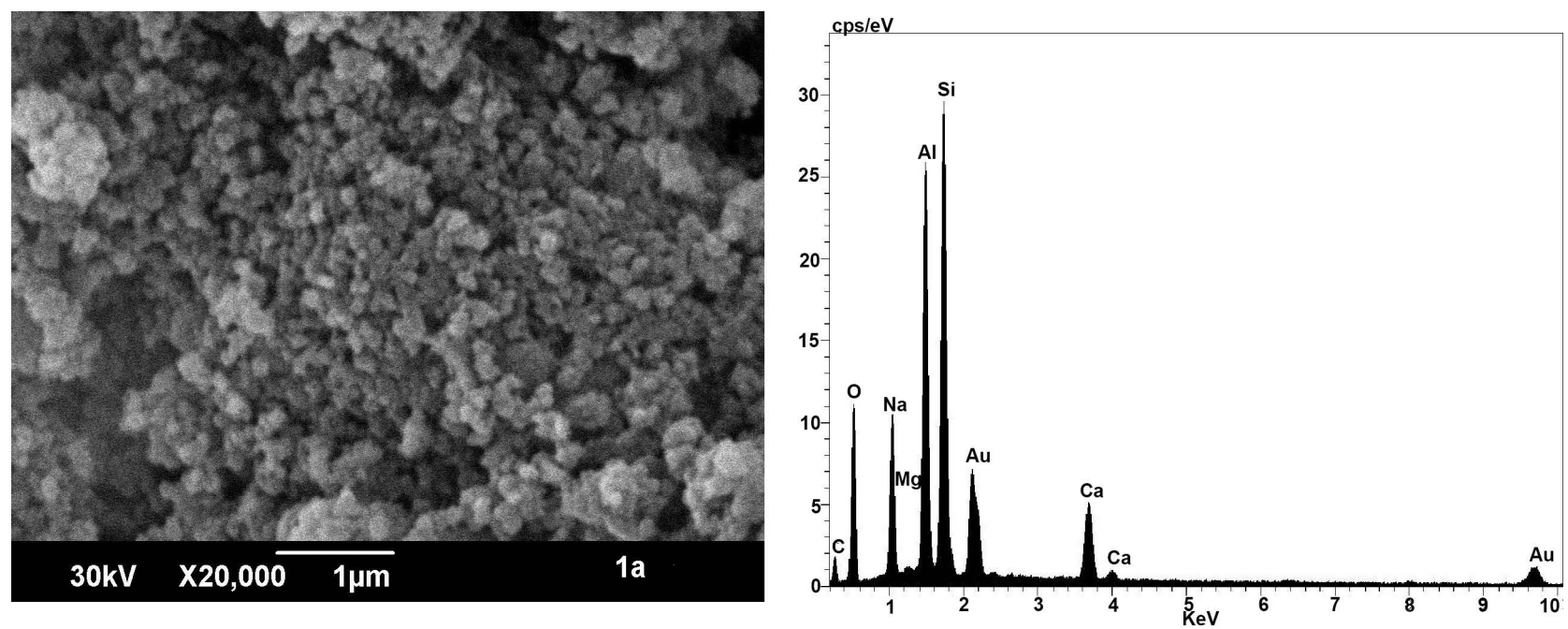

Figure 2. SEM image (left) and EDX-spectrum (right, field analysis) of sample 1a. 
The SEM image of product $1 \mathrm{~b}$ shows mainly agglomerates/aggregates of FAU crystals and a few FAU crystals with octahedral habit (see Figure 3 ). The crystal size within this sample varied from 0.5 to $2 \mu \mathrm{m}$.

The chemical composition amounts (Wt.\%): $\mathrm{SiO}_{2}: 44.5 ; \mathrm{Al}_{2} \mathrm{O}_{3}: 36.3 ; \mathrm{Na}_{2} \mathrm{O}$ : 18.8; $\mathrm{CaO}: 0.4$. The Si/Al-ratio is 1.0. Due to this ratio the exact classification of the FAU-form is complicated and according to the chemical analysis it is probably the LSX-form.

A comparison of analyses data of sample $1 \mathrm{~b}$ with $1 \mathrm{a}$ exhibits an enrichment of $\mathrm{Si}-, \mathrm{Ca}-$ and $\mathrm{Mg}$ - in the bottom product 1a.

Figure 4 presents well formed intergrowth of the LTA parts within product 1b. The size of the crystals varies between $2-3 \mu \mathrm{m}$. The composition of the LTA crystals is (Wt.\%): $\mathrm{SiO}_{2}: 43.2 ; \mathrm{Al}_{2} \mathrm{O}_{3}: 35.9 ; \mathrm{Na}_{2} \mathrm{O}: 20.6$; $\mathrm{CaO}: 0.3$. The $\mathrm{Si} / \mathrm{Al}$-ratio is 1.0 .

\subsection{Samples $2 \mathrm{a}$ and $2 \mathrm{~b}$}

The X-ray powder pattern of sample 2 a shown in the $3^{\circ}-40^{\circ} 2$ Theta range for a better overview in Figure 1, reveals the formation of FAU. The FAU again crystallised in the form of FAU-EMT (PDF 38-237/PDF 46-566 [34]) as already described for the powder pattern of product 1a. Again the broad reflections and the strong background contribution is a sign for very small crystals and a low degree of crystallinity of the whole sample. Compared with the powder pattern of sample la now the crystallization of zeolite LTA seems to be widely suppressed. Only a very weak developed and very wide reflex around $7.2^{\circ} 2$ Theta (the main line of LTA [34]) which is hardly distinguished from the background of the pattern, is a hint on traces of Zeolith LTA.

The SEM image, Figure 5, shows small and isometric crystallites and agglomerates. The size of the crystallites amounts under $0.1 \mu \mathrm{m}$.

The chemical composition is (Wt.\%): $\mathrm{SiO}_{2}: 46.0 ; \mathrm{Al}_{2} \mathrm{O}_{3}: 32.6 ; \mathrm{Na}_{2} \mathrm{O}: 13.8 ; \mathrm{CaO}$ : 6.6; MgO: 1.0. The Si/Al-ratio is 1.2.
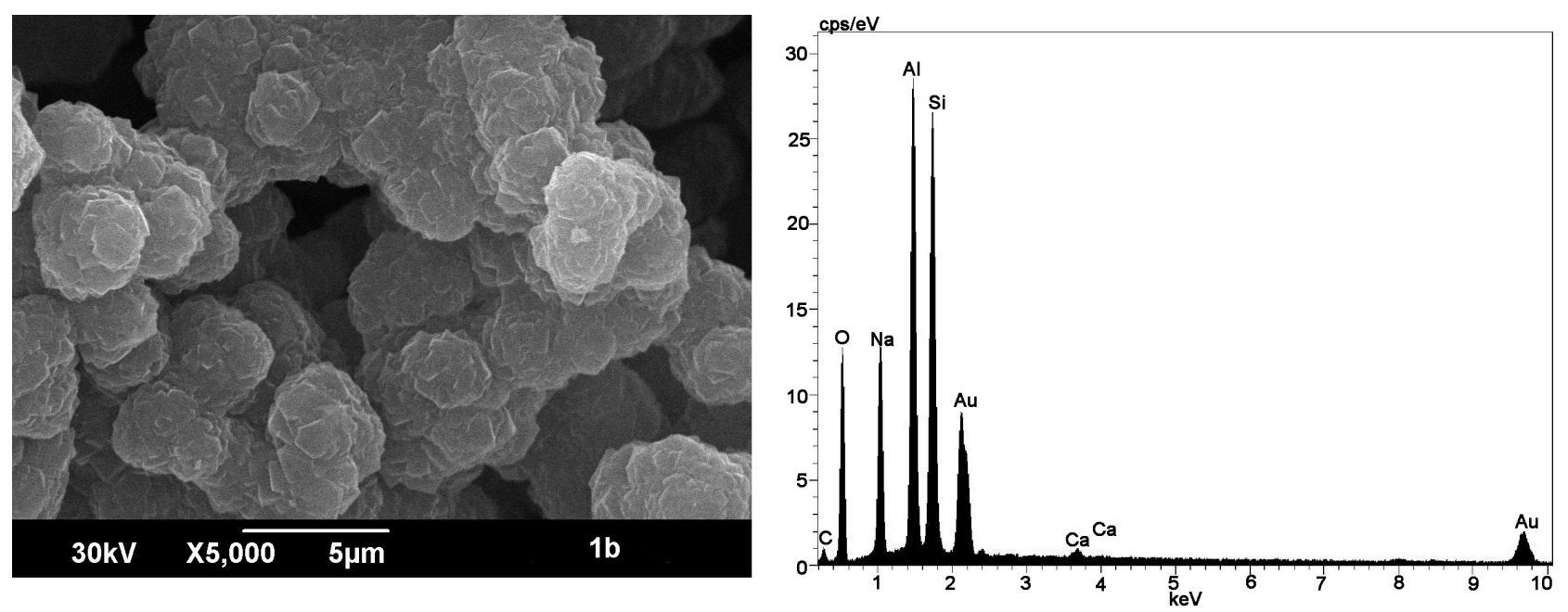

Figure 3. SEM image (left) and EDX-spectrum (right, field analysis) of sample $1 \mathrm{~b}$. 

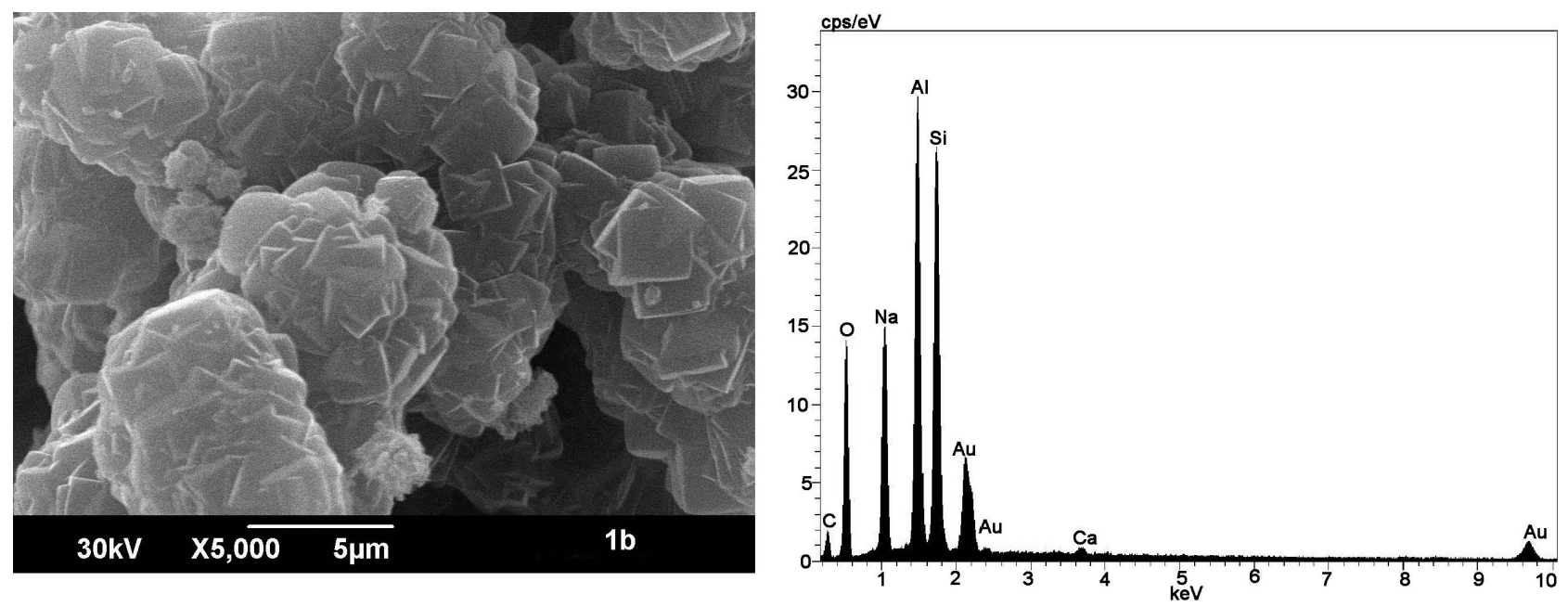

Figure 4. SEM image (left) and EDX-spectrum (right, field analysis) of the LTA part of sample 1b.
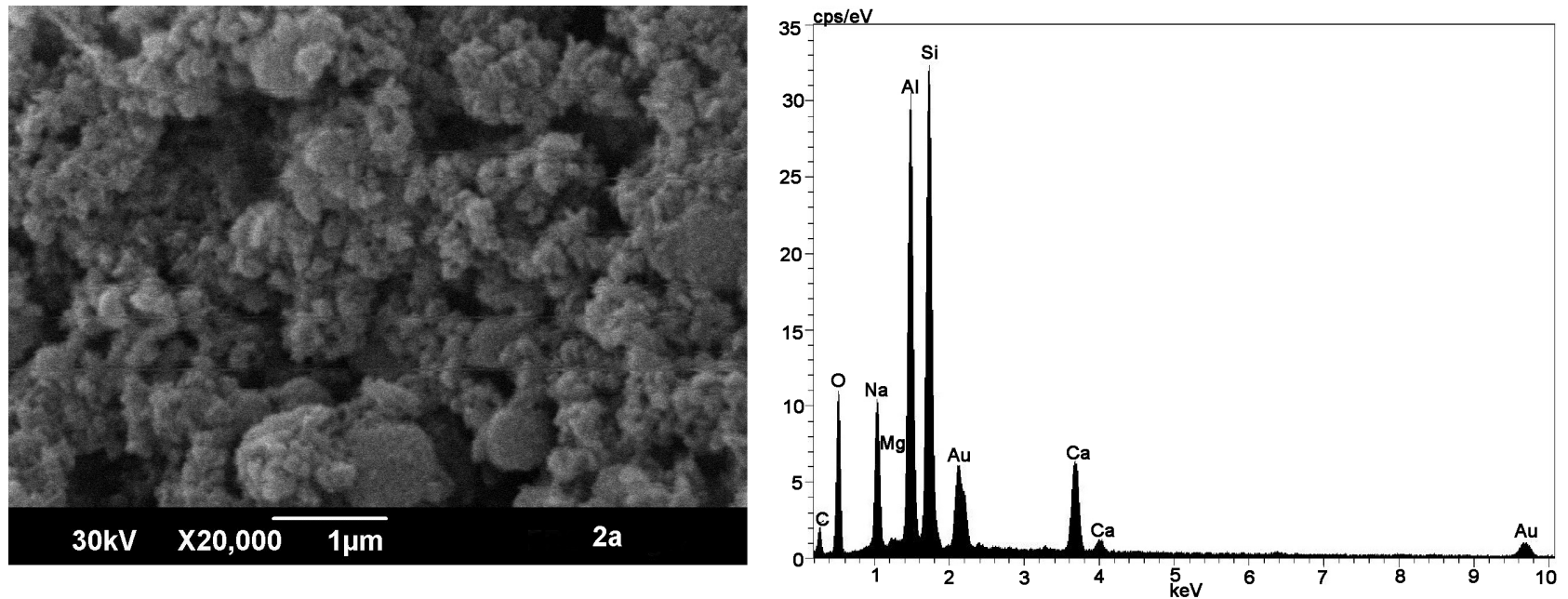

Figure 5. SEM image (left) and EDX-spectrum (right, field analysis) of sample 2a.

The XRD analysis of the product $2 \mathrm{~b}$ (Figure 1 ) points FAU-EMT zeolite intergrowths (PDF 38-327/PDF 46-566 [34]) and a small quantity of LTA.

On the SEM photo, Figure 6, panel-shaped crystals of FAU-EMT can be seen. The panels often lay perpendicular to the visible surface and appear therefore as stretched columns. The size of the crystals corresponds on average to $0.2-0.3 \mu \mathrm{m}$.

The chemical analysis (Wt.\%) of the sample is: $\mathrm{SiO}_{2}: 44.5 ; \mathrm{Al}_{2} \mathrm{O}_{3}: 35.4 ; \mathrm{Na}_{2} \mathrm{O}$ : 19.8; $\mathrm{CaO}: 0.3$. The $\mathrm{Si} / \mathrm{Al}$-ratio varies below 1.1 and again an exact classification of the FAU-form is complicated and according to the chemical analysis it is probably the LSX-form.

A comparison of analyses data of sample $2 \mathrm{~b}$ with $2 \mathrm{a}$ again shows the enrichment of $\mathrm{Si}$-, Ca- and $\mathrm{Mg}$ - in the bottom product $2 \mathrm{a}$.

\subsection{Samples 3a and 3b}

The X-ray powder pattern of product 3a shows wide and rather vague reflexes and the background contribution is high. The zeolite phase FAU-EMT (PDF 

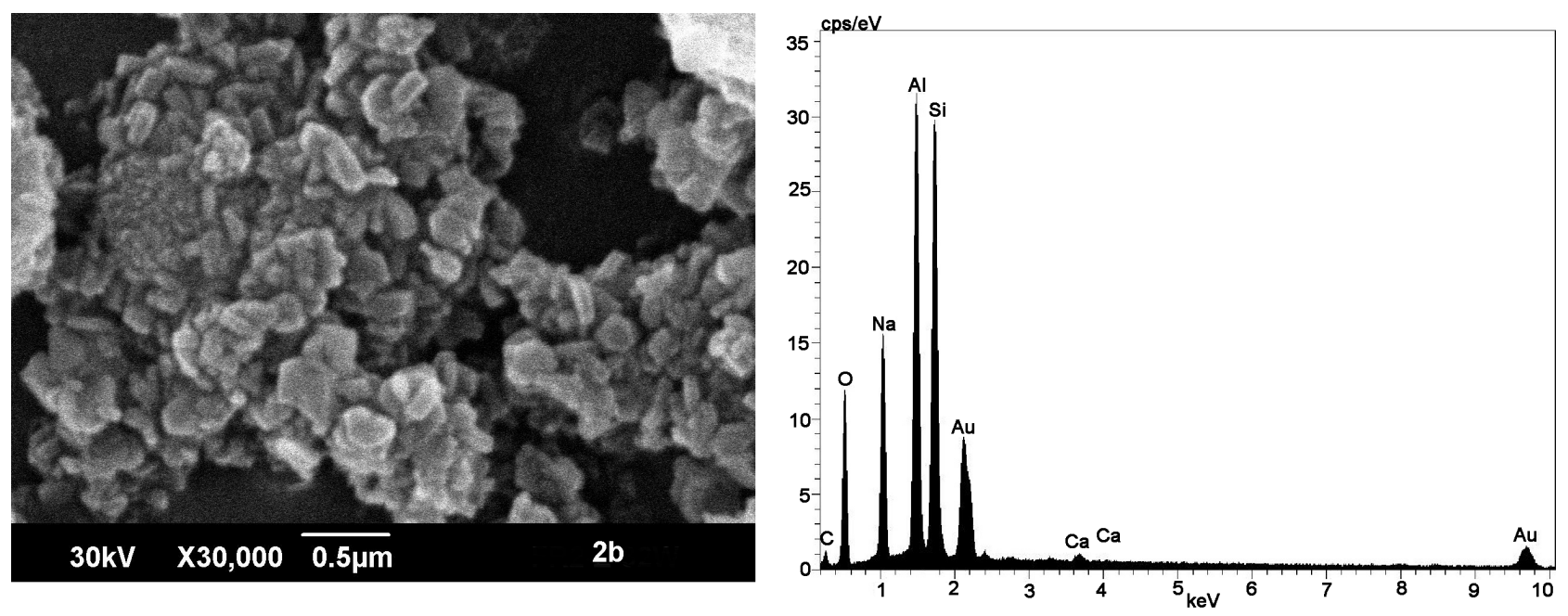

Figure 6. SEM image (left) and EDX-spectrum (right, field analysis) of sample 2b.

38-237/PDF 46-566 [34]) could again identify. The sample contains no LTA. The SEM picture, Figure 7, presents isometric crystallites and spherical agglomerates. The crystallite size is smaller than $0.1 \mu \mathrm{m}$.

The EDXS field analysis at this area shows the following composition (Wt.\%): $\mathrm{SiO}_{2}: 47.1 ; \mathrm{Al}_{2} \mathrm{O}_{3}: 30.3 ; \mathrm{Na}_{2} \mathrm{O}: 12.8 ; \mathrm{CaO}: 8.8 ; \mathrm{MgO}: 1.0$. The ratio $\mathrm{Si} / \mathrm{Al}$ is equal 1.3 .

The powder pattern of product $3 \mathrm{~b}$ points to FAU-EMT zeolite and as sample 3a even no LTA (Figure 1). The main reflex of FAU with approx. $6.1-6.2^{\circ} 2$ Theta exhibits now better resolved shoulders around 5.8 and $6.6^{\circ} 2$ Theta, according to somewhat larger degree of EMT intergrowths.

In the SEM investigation sample $3 \mathrm{~b}$ shows close resemblance with the synthesis product $2 \mathrm{~b}$. In Figure 8 panel-shaped crystals of FAU-EMT can be seen. The FAU-EMT panels are often arranged vertically to the visible surface and appear as stretched columns. The size of the crystals corresponds on average to $0.2-0.3$ $\mu \mathrm{m}$.

The chemical analysis of the sample $3 \mathrm{~b}$ represents (Wt.\%): $\mathrm{SiO}_{2}: 46.1 ; \mathrm{Al}_{2} \mathrm{O}_{3}$ : 35.2; $\mathrm{Na}_{2} \mathrm{O}: 17.8 ; \mathrm{CaO}: 0.9$. The $\mathrm{Si} / \mathrm{Al}$-ratio is 1.1. A comparison of the analyses data of sample $3 \mathrm{~b}$ with $3 \mathrm{a}$ again shows the enrichment of $\mathrm{Si}-$, $\mathrm{Ca}-$ and $\mathrm{Mg}$ - in the bottom product $3 \mathrm{a}$.

\section{Conclusions}

Low temperature synthesis using an industrial waste material "filtration residue FR" from waste water reconditioning of the silane production as substitute for sodium silicate, mainly yields to disordered intergrowths of zeolite FAU-EMT. More or less amounts of zeolite LTA were observed as byproducts in the $40^{\circ} \mathrm{C}$ and $30^{\circ} \mathrm{C}$ synthesis. A product without parts of zeolite LTA could be synthesized at only $25^{\circ} \mathrm{C}$.

Syntheses were successfully performed under open conditions without stirring. The starting material FR was used without an energy consuming pre-treatment like calcination. 

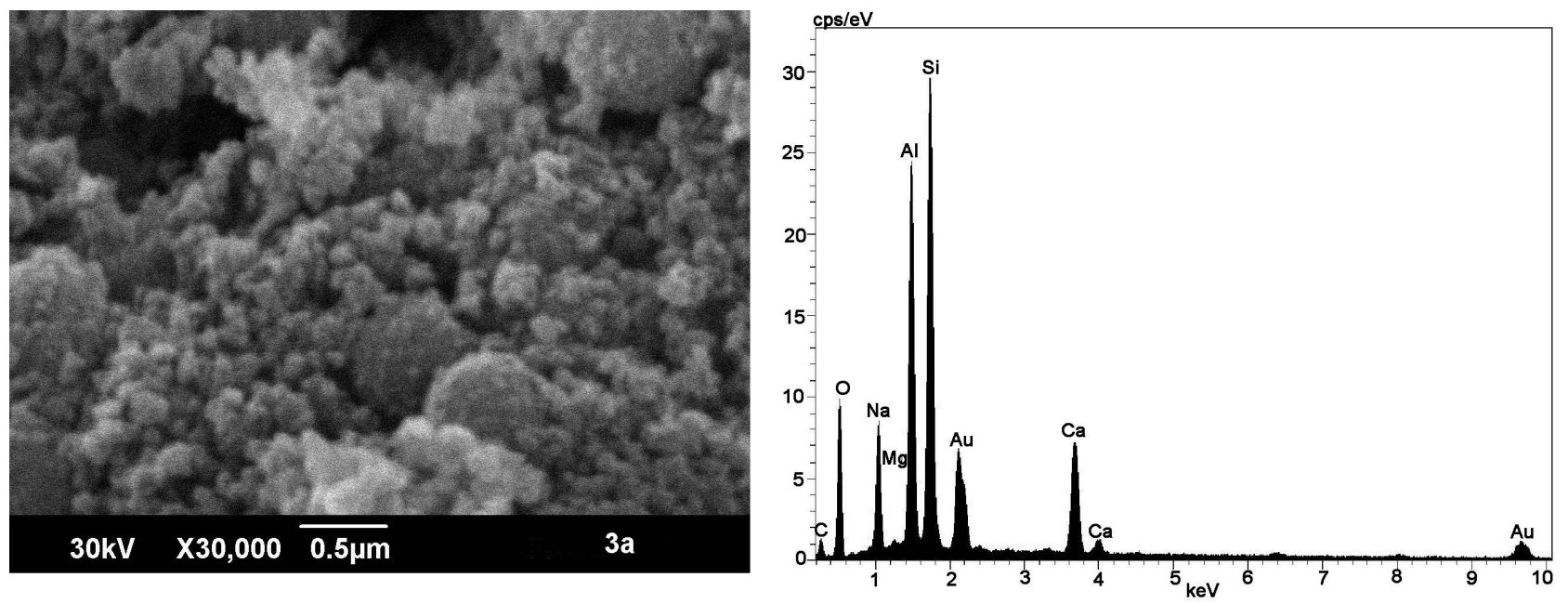

Figure 7. SEM image (left) and EDX-spectrum (right, field analysis) of sample 3a.
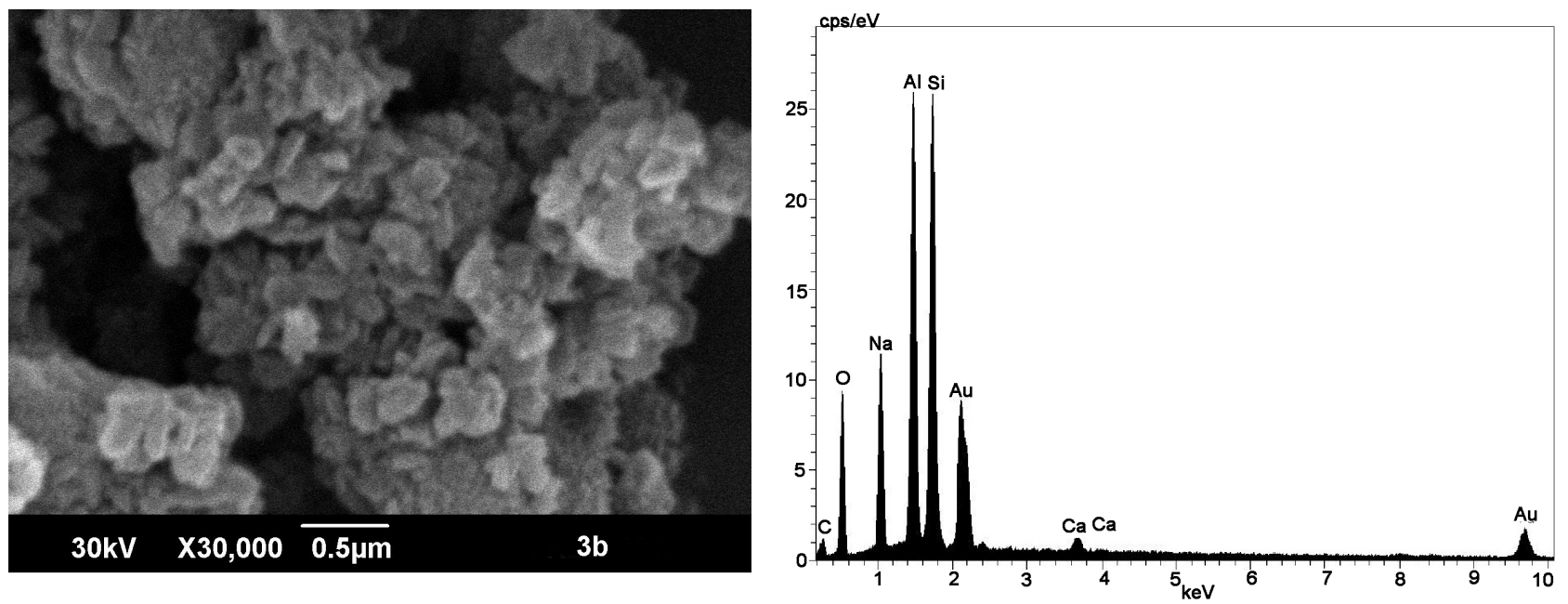

Figure 8. SEM image (left) and EDX-spectrum (right, field analysis) of sample $3 \mathrm{~b}$.

An optimization of gel formation was reached by the addition of citric acid. The latter caused an additional proton enrichment of the sol/gel in an alkaline environment and is thus reducing the polymerization and avoids a too fast flocculation of the gel [28] [29]. Furthermore the acid is a suitable buffer to rule the kinetics of the reaction course due to its dissociation strength.

The reaction products always occurred in two sequences, one at the bottom of the reaction vessel and another at the top with portions of amorphous aluminosilicate within both parts. In general a comparison of analyses data showed a higher crystallinity of the products formed at the top of the crystallization bin. The concentrations of $\mathrm{Ca}$ and $\mathrm{Mg}$ accumulated in the bottom products and even the Si/Al-ratio of the FAU-EMT products were always higher in the lower crystallization area, than at the top. In general a remarkable low Si:Al ratio was analyzed in the FAU-EMT intergrowths, especially in the products from the top of the reaction bin and a LSX like composition of the FAU parts of the intergrowth cannot excluded. 
Future investigations on the mechanism of zeolite formation from industrial residues like FR at low temperatures are necessary. An improvement of the crystallinity of the samples by fine tuning of the preparation steps at $25^{\circ} \mathrm{C}$ is an interesting topic for such an upcoming work. Even the characterization of the pore system according to BET-analysis and tests of sorption properties and thermal stabilities should be included in future experimental studies of the FAU-EMT zeolites.

\section{Acknowledgements}

The authors like to thank Dr. K. Rübner, BAM-Federal Institute for Materials and Testing Berlin, for kindly providing the FR raw material and for performing the chemical analysis of FR.

\section{References}

[1] Aiello, R., Colella, C., Casey, D.G. and Sand, L.B. (1980) Experimental Zeolite Crystallization in Rhyolitic Ash-Sodium Salt Systems. In: Rees, L.C.V., Ed., Proceedings of the 5 th International Zeolite Conference, London, 49-55.

[2] Höller, H. and Wirsching, U. (1985) Zeolite Formation from Fly Ash. Fortschritte der Mineralogie, 63, 21-43.

[3] Grutzeck, M. and Siemer, D.D. (1997) Zeolites Synthesized from Class F Fly Ash and Sodium Aluminate Slurry. Journal of the American Ceramic Society, 80, 2449-2453. https://doi.org/10.1111/j.1151-2916.1997.tb03143.x

[4] Maenami, H., Shin, H., Ishida, H. and Mitsuda, T. (2000) Hydrothermal Solidification of Wastes with Formation of Zeolites. Journal of Materials in Civil Engineering, 12, 302-306. https://doi.org/10.1061/(ASCE)0899-1561(2000)12:4(302)

[5] Miyake, M., Tamura, C. and Matsuda, M. (2002) Resource Recovery of Waste Incinerator Fly Ash: Synthesis of Zeolites A and P. Journal of the American Ceramic Society, 85, 1873-1875. https://doi.org/10.1111/j.1151-2916.2002.tb00368.x

[6] Murayama, N., Yamamoto, H. and Shibata, J. (2002) Zeolite Synthesis from Coal Fly Ash by Hydrothermal Reaction Using Various Alkali Sources. Journal of Chemical Technology and Biotechnology, 77, 280-286. https://doi.org/10.1002/jctb.604

[7] Rios, C.A. and Williams, C.D. (2008) Synthesis of Zeolitic Materials from Natural Clinker: A New Alternative for Recycling Coal Combustion By-Products. Fuel, 87, 2482-2492.

[8] Anuwattana, R. and Khummongkol, P. (2009) Conventional Hydrothermal Synthesis of Na-A Zeolite from Cupola Slag and Aluminium Sludge. Journal of Hazardous Materials, 166, 227-232.

[9] Wajima, T., Haga, M., Kuzawa, K., Ishimoto, H., Tamada, O., Ito, K., Nishiyama, T., Dows, R.T. and Rakovan, J.F. (2006) Zeolite Synthesis from Paper Sludge Ash at Low Temperature $\left(90^{\circ}\right)$ with Addition of Diatomite. Journal of Hazardous Materials, B132, 244-252.

[10] Wajima, T., Ishimoto H., Kuzawa K., Ito K., Tamada O., Gunter M.E. and Rakovan J.F. (2007) Material Conversion from Paper-Sludge Ash in $\mathrm{NaOH}, \mathrm{KOH}$, and $\mathrm{LiOH}$ Solutions. American Mineralogist, 92, 1105-1111. https://doi.org/10.2138/am.2007.2251

[11] Mun, S.P. and Ahn, B.J. (2001) Chemical Conversion of Paper Sludge Incineration Ash into Synthetic Zeolite. Journal of Industrial and Engineering Chemistry, 7, 
292-298

[12] Wajima, T. und Ikegami, Y. (2008) Zeolite Synthesis from Paper Sludge Ash via Acid Leaching. Chemical Engineering Communications, 195, 305-315. https://doi.org/10.1080/00986440701555258

[13] Hartmann, A., Petrov, V., Buhl, J.-C., Rübner, K. and Lindemann, M. (2016) Digestion Reactions of Paper Sludge Combustion Ash in Strong Alkaline Solutions at $60^{\circ} \mathrm{C}$. Journal of Material Cycles and Waste Management, 18, 132-145. https://doi.org/10.1007/s10163-014-0320-4

[14] Hartmann, A., Petrov, V., Buhl, J.-C., Rübner, K., Lindemann, M., Prinz, C. and Zimathies, A. (2014) Zeolite Synthesis under Insertion of Silica Rich Filtration Residues from Industrial Wastewater Reconditioning. Advances in Chemical Engineering and Science, 4, 120-134. https://doi.org/10.4236/aces.2014.42015

[15] Hartmann, A., Petrov, V., Buhl, J.-C., Rübner, K. and Lindemann, M. (2016) Electrostatic Filter Ash from Silane Production as Substitute in Zeolite Chemistry. Zeitschrift für anorganische und allgemeine Chemie, 642, 472-479.

https://doi.org/10.4236/aces.2014.42015

[16] Breck, D.W. (1976) Zeolitovie molekuljarnie sita. [Zeolite Molecular Sieves.] Mir, Moskva.

[17] Zhdanov, S.P., Hvotschev, S.S. and Samulevich, N.N. (1981) Sinteticheskie zeoliti: kristallisazija, strukturno-chimicheskoe modifizirovanie i adsorbzionnie svoistva. [Synthetic Zeolites: Crystallization, Structure-Chemical Modifications and Adsorption Properties.] Chimija, Moskva.

[18] Barrer, R.M. (1982) Hydrothermal Synthesis of Zeolites. Academic Press, New York.

[19] Petrov, V.D., Koglin, T. and Buhl, J.-C. (2013) Kokristallisation und Kristallmorphologie der Zeolithe LTA und X (FAU) bei der Hydrothermalsynthese silikatreicher Gele. [Co-Crystallization and Crystal Morphology of Zeolites LTA and X (FAU) during Hydrothermal Synthesis from Silica Rich Gels.] 21 st Annual Conference of the German Crystallographic Society, from Symmetry to Function, Freiberg 2013, Zeitschrift für Kristallographie Supplements Issue No. 33 PS 05-P49, 98-99.

[20] Fischer, F., Hadan, M. and Horn, A. (1991) Zeolite Syntheses from Superalkaline Reaction Mixtures. Chem. Technol., Nr. 43, 191-195.

[21] Fischer, F., Hadan, M. and Fiedrich, G. (1992) Zeolite Syntheses from Superalkaline Reaction Mixtures. Collection of Czechoslovak Chemical Communications, 57, 788-793. https://doi.org/10.1135/cccc19920788

[22] Hadan, M. and Fischer, F. (1992) Synthesis of Fine-Grained NaA-Type Zeolites from Superalkaline Solutions. Crystal Research and Technology, 27, 343-350. https://doi.org/10.1002/crat.2170270310

[23] Ng, E.-P., Goupil, J.-M., Vicente, A., Fernandez, C., Retoux, R., Valtchev, V. and Mintova, S. (2012) Nucleation and Crystal Growth Features of EMT-Type Zeolite Synthesized from an Organic-Template-Free System. Chemistry of Materials, 24, 4758-4765. https://doi.org/10.1021/cm3035455

[24] Ng, E.-P., Awala, H., Tan, K.-H., Adama, F., Retoux, R. and Mintova, S. (2015) EMT-Type Zeolite Nanocrystals Synthesized from Rice Husk. Microporous and Mesoporous Materials, 204, 204-209. https://doi.org/10.1016/j.micromeso.2014.11.017

[25] Hartmann, A. and Buhl, J.-C. (2008) Investigation on Sodalite Crystallization from 
Autoclaved Aerated Concrete Residues and Sodium Aluminate. Zeitschrift für Kristallographie Supplements Issue, 28, $1 \mathrm{C} 06$.

[26] Hartmann, A., Buhl, J.-C. and Lutz, W. (2011) Book of Abstracts, 23. Deutsche Zeolith-Tagung: 02. bis 04. März 2011, Friedrich-Alexander-Universität ErlangenNürnberg, 104-105.

[27] Rübner, K. (2014) Personal Communication. Bundesanstalt für Materialforschung BAM, Berlin.

[28] Iler, R.K. (1982) Chimija kremnezema. Rastvorimost, polimerizazija, kolloidnie i poverchnostnie svoistva, biochimija. [Chemistry of Silica. Solubility. Polymerization, Colloidal- and Surface Properties, Biochemistry.] Mir, Moskva.

[29] Chukin, G.D. (2008) Chimija poverchnosti i stroenie dispersnogo kremnezema. [Chemistry, Surface and Structure of Disperse Silica.] Paladin, Moskva.

[30] Nemati, M.M. (2013) Herstellung und Kristallisationsverhalten von ZeolithPrecursor Gelen aus Sodalith und Cancrinit. Masterarbeit. [Preparation and Crystallization Behaviour of Zeolite Precursor Gels from Sodalite and Cancrinite.] Institut für Mineralogie, 112 Leibniz Universität, Hannover.

[31] Buschuev, Ü.G. (2011) Zeoliti. Kompjuternoe modelirovanie zeolitnih materialov. Ivanovo State Chem.-Technol. University, Ivanovo, Russia.

[32] Treacy, M.M.J. and Higgins, J.B. (2001) Collection of Simulated XRD Powder Patterns for Zeolites. Elsevier, Amsterdam.

[33] Baerlocher, C., Meier, W.M. and Olson, D.H. (2001) Atlas of Zeolite Framework Types. Elsevier, Amsterdam.

[34] International Centre for Diffraction Data, 12 Campus Boulevard, Newton Square, Pennsylvania 190073-3272, USA. 